\title{
The Role of Women in Raja Rao's Fiction- A Feminist Perspective
}

\author{
Dr. Venkateswarlu Yesapogu, M.A., M.Phil, PhD. Head \\ Associate Prof. in English, Principal FAC in V.V. \& M Gov't Aided Degree College \\ Ongole, Prakasam D.T., A.P. India \\ Yvghosh.yvghosh@gmail.com
}

\begin{abstract}
As a fictional artist, Raja Rao has created an impressive gallery of women characters who in many ways represent, perhaps more authentically then men,the spirit of the age in which Indian society has been passing from the old traditions to the contemporary situations. With a deep sympathy towards, and understanding of, the feminine psyche, Raja Rao has come to view woman as a primordial force consciously or unconsciously forging the destiny of man and his world. In fact the builds up a whole myth around woman drawn from the vedic tradition and updated till the advent of the liberated woman of our times. As is observed in The Serpent and the Rope:

However, for my article presentation I have chosen the title "The role of women in Raja Rao's fiction - A feminist Perspective", which explores the status of woman and its role in all Raja Rao's fiction. Woman is the earth, air, ether, sound; women is the microcosm of the mind, the articulation of space, the knowing in knowledge; the woman is fire, movement, clear and repid as the mountain stream; the woman is that which seeks against that which is sought. To Mitra she is Varuna, to Indra she is Agni, to Rama she is Sita, to Krishna she is Radha. Woman is the meaning of the word, the breath, touch, act; woman that which reminds man of that which he is and reminds herself through him of that which she is. Woman is kingdom, solitude, time; woman is growth, the gods inherence; the woman is death, for it is through woman that one is born, woman rules; for it is she, the universe. This attitude of idealisation of womanhood is developed through successive novels from Kanthapura to Comrade Kirillov.
\end{abstract}

Keywords: Woman, earth, feminine Psyche, destiny, tradition, universe.

\section{INTRODUCTION}

Raja Rao is from a South Indian orthodox Brahmin family in the princely state of Mysore. He was born in 1909. Right from his birth Raja Rao has been an exile linguistic, religious and cultural. He was the only Hindu pupil in the Muslim public school of Hyderabad. His higher education took place in the Muslim university of Aligarh in the British India. Prof. Eric Dickinson impressed Raja Rao "to love France" and to appreciate Michaelangelo and Santayana" After graduation, Raja Rao left India to study at Montpellier, France in 1929. Soon after his arrival, he married Camille Mouly, a highly educated French woman who taught at Lycée in Menton. A Brahmin's marriage with a foreigner happens to be in reality an act of rebellion against the Hindu Orthodoxy and Rao himself is the best Hindu orthodoxy and Rao himself is the best commentator in the regard. He says "we are Hoyasalas of Karnataka, we marry only among ourselves " and "I was the eldest son's. In the south, he has got a very special place, so I was chosen to continue the line. I was the specifically favoured one." It is a moot question how a Hoyasala of Karnataka married to a French woman can fulfil his brahminic commitment and this restlessness in Rao led to abandon the research project entitled ". "The influence of India on Irish Literature ". He was very much influenced by The Ramayana, The Mahabharata, BrihastotraRatnakara. In Rao's view man is a meta- physical entity, as his greatness lies in the process of transformation of this whole corpus of subjective experience in to a sufficient art form. Raja Rao is an expatriate Indian in the fullest sense of the term because once he left India for his higher education in France; he has been practically outside India, making only occasional visits to his mother land. He taught philosophy at Texas, which accounts for the abundant philosophical and metaphysical concerns in his writings. Raja Rao is a real expatriate in his life time and Ramaswamy and SivaramaSastri the protagonists in the novels are the fictional selves of Raja Rao. 
Raja Rao's heroes see in the women not individuals but archetypist symbolic figures, close to their hears; woman, mysterious, powerful, sensual, sensuous, compassionate, child- mother- bridebeloved, all in one. Small wonder that the Freud- oriented Westerner is moved to extravagent tribute or caustic contempt.

The Cow of the Barricades and other Stories published in 1947, is the first collection of short stories. The second collection, The policeman and the Rose is brought out with the addition of three new stories in place of the two old ones of the former. As C.D. Narasimhaiah remarks these are " the products of an inevitable stage in the growth of a mind, in the evolution of a major novelist who was cultivating his craft with the utmost care,... ".

The gentle, submissive and innocent nature of the rural, household characters and the simple and unsophisticated lives they lead are presented realistically in these short stories. They represent Indian life revealing a metaphysical vein understanding all its past conventions and customs as well as the attitudes of the evolving generations. With his intimate knowledge of Indian life Raja Rao explores the inner psyche, the human condition as it shapes and is shaped, through the medium of an alien language.

Of particular relevance are the four short stories "Javni", " Akkayya", "Nimka" and " The Cow of the Barricades ", in which Raja Rao presents sharply differentiate character types of Indian womanhood" Javni" presents the pathetic tale of a low- caste widow, who works in a middle class Brahmin family more for the affection she receives than for the money she earns. "she was past forty, a little wtlrinkled beneath the lips and with strange, rapturous eyes. Her hair was turning white. . . . and her bare, broad fore head showed pain and widowhood".

The story is narrated by Ramappa, an English educated boy, brother of sita for whom Javni works. His relationship with Javni, the maidservent rests on metaphysical grounds. They share the same religious nature, only he, at the level of Vedanta and she a devout believer in superstitions and the village goddess Talakamma. We see through the eyes of the narrator the pitiable condition of an old lady bearing all the insults with good natured patience in the same way as she accepts her allotted place in society with unquestioning humility.

At javni's initial meeting with Ramappa, she compares him to a saint, a holy elephant and God. Sita by comparison refers to him as a Prince, pointing to the Ramayana from which their names are taken. She in turn refers to Javni as a " little monkey", however, Ramappa compares her with the cow, the sacred animal for Hindus, as it stands for the eternal endurance and patience of India. The cow is also looked upon as the incarnation of mother- love. As the animal patiently serves man, Javni also in the same way has served hundereds of revenue inspectors who bring families to her town for a year or two and then move on, transferred to some other place. Javni spends most of her time in the backyard talking to the calf. She eats with the cow and swallows mouthfuls of rice "that sounded like a cow chewing the cud". (P.88). Like the cow she eats in the dark and is not offended when a heapful of dung splashes while she is eating. Rama feels it as inhuman and not religious to put Javni with the cows, while Sita observes that mixing of castes is irreligious. Ironically, Javni's views also coincide with Sita's views. She accepts the teachings of the dominant caste and learns to live resigned to the discomfort imposed by the customs of a rigid society. Ramu percieves Javni as a divine being and thinks that such saintlike nature becomes only noble souls like her.

The relation between Javni and Ramappa is handled exceedingly well. The relation between Sita and Javni is rather undeveloped. The narrator says that Javni and Sita are quite good friends, but Sita's conversation and behaviour does not imply the narrator's assertion. Javni's charm lies in her simplicity. When the time comes to depart from that place, Javni's eyes are filled with tears. Ramappa is also sad, as he records: " I got into the cart with a heavy heart. I was leaving a most wonderful soul".(p.96).

The only adequate tribute to Javni is the popular view: "Javni, she is good like a cow. In "Akkayya" we see another self-sacrificing woman, a typical feature in many Indian homes. An old woman widowed in her childhood sets up herself as a mother to all the children in the family and also to the orphans around the family, "And when the children left her, she forgot them as the cow forgets the young ones. But God always supplied her with Orphan children ". . . . ( P.50).

We see her again as Aunt Lakshamma in The Serpent and the Rope. She was married to a minister once, and he died when she was seven or eight. And since then my uncles and their daughters, my 
mother's cousins and their grandchildren have always had Aunt Lakshamma to look after them, for an Orphan in a real household is never an Orphan in a real household is never an Orphan.

Javni and Akkayya symbolise the silent heroism and selfless sacrifice of Indian womanhood, says Dr.K.S.Iyengar. " Nimka" shows Raja Rao's flair for the meta- physical aspect which often recurs in his themes. He is more interested in dealing with the abstract truths underlying the concrete reality. In the story, the narrator despises the mournful sadness of Nimka as she is changed into an angel- like beauty by her vitue and calm nature and to highlight all by the purity of her love. " Nimotchaka was good, very good, and of a simple true beauty, as through you could not efface it even were you to cut her face with many crosses. Her beauty had certainty, it had a rare equilibrium, and a naughtiness that was feminine and very innocent ". (P.99).

The narrator fails to win the love of Nimka Being an Indian he is " too far, distant and different ".(p.102). for her. She falls in love with Michel, but his desperateness creates a void between them. Even in sorrow Nimka looks dignified. She stands as a representative of India even as Michel represents Europe; both differ in their sets of values and modes of being. Yet these two contrasting cultures are brought to a point of convergence by the connection in time between Gandhi and Tolstoy.

Finally, she marries Count Vegilian Kormaloff. Having gone bankrupt he drifts to Monte Carlo to make money, leaving his wife Nimka and son Boris to themselves. She takes up the career of a model during the war time to bring up her son. But when he comes of age, he leaves for Russia and Nimka, the helpless mother is left along for all the care she has taken for the child of her own blood.

The account of Mahatma Gandhi's assassination adds a depth of pathos to Nimka's own sorrowful tale. Thus the story presents the tragedy of Nimka's love and life. Despite her remarkable amiability and stunning beauty she fails both in her love and life. At the end we are deeply touched to see such an end to a righteous person like nimka.

"Nimka was not sad. Her heart contained an intimacy of Sorrow that was almost kin of joy...nimka asked nothing of life. She asked nothing of me...... She knew the life that has ended is eternal". (P.103).

With his characteristic cosmopolitan out lock, Raja Rao employs a unique poetic style in tha narrative, blending artistically the outcoming sentiments with his scientillatting ideas. A rare concept of beauty is unearthed from the depths of his artistic intelligence.

In the title story "The com of the Barricades", Gowri, the cow is the control figure,she is viewed as mother-love, kamadhenu, the com of plenty and Bharatamathe. She assumes a divine status having the the power of miracles for the people who seek to fulfill their aspirations by touching her tail or by falling at her feet. Master describes her as "The great mothers vehicle". (9.36). Gandhi 's non-violence in the freedom struggle creates a tense situation. The people of the town start building barricade after barricade, though the Master warnsthem that everything will be peaceful. The Master who is supposed to lead the people starts meditation to avoid bloodshed. On one side of the Barricades the people stand with their weapons and on the other side, the military. The night falls on and in thet tense moment, Gowri , the compassionate cow comes and moves up to the top of the barricades. People greet the with "vandemataram", while the military on the other side are puzzled boubting whether the cow stood there as a flag of truce. "When their saw the com and its looks and the tear, clear as a drop of the Ganges, they shouted out, 'victory to the mahatma! Mahatma Gandhi ki jai' ! and joined up with the crowd man, saw this and fired a shot. It went through Gowri 's head, and she fell, a vehicle of God among lowly men". (p.41).

Thus Gowri, the sacred spirit sacrificed its lift at the altar of non-violence. She stands as a symbol of the power of love. Greathess is attributed to those who lay down their lives for the sake of their country. Whether the martyr is a human being or an animal does not matter, because both...."are animated by the same divine spark of live that " sweeps through the dull dense world, compelling there, all new succession to the forms they wear "but a more fundamental and familiar symbol to which Hindus respond readily, the cow as the mother, mother India, and shakti". She is the mother principle subsequently elaborated in The serpent and the Rope and around which The cat and Shakespeare is wover. The worship of woman and the cow goes back to the ancient times of the prevedic period. "Aditi, the mother of the gods is described both as the cow and as the general Mother; she is the Supreme Light and all radiances proceed from her. 
In these stories Raja Rao satirically comments on the weak points of the social conventions, beliefs and institutions. The themes and techniques vary from story to story, but the emphasis is laid mainly on the human values. Raja Rao cannot resist his characteristic habit of turning a social or psychological situation into an aspect of truth with metaphysical significance. As prof. C.D. Narasimhaiah remarks: . . the religious impulses and the metaphysical imagination are unmistakable even in these.

Raja Rao's short stories deal with the social and esthetic problems; both being the two patterns of life. The women characters in these short narratives are extended from types into individuals, and from ordinary figures of Indian social reality into symbolic figures of myth and allegory. In her patience, endurance, fortitude, self- sacrifice and compassionate maternal instinct, woman in Raja Rao's short stories prefigures the more fully developed view of woman as shakti, which one finds in the novels.

\section{CONCLusion}

In India villages normally consist of a cluster of houses huddled together. So the villagers tend to know more about each other. To a village woman, not only the members of her household but the whole village is familiar. By instinct she is curious to know what's going on around her. She is constantly aware of the personal problems of the inhabitants, their mannerisms, their good points and their general weaknesses. The village is her court- yeard and doing her work she harangues with the other members of the village, who also richly contribute their share of gossip. No secret survives and everything is plain and open to them. Achakka, the narrator in Kanthapura is a typical village woman and the village Kanthapura resembles one single household. The tiny village stepped in its superstitious, orthodox and extreme conservatism is drawn into the swirling current of the freedom struggle. The impact of Gandhi's ideals and principles arouse sentiments and emotions and pave the way for a non- violent struggle against the imperialistic regime. The whole village heroically fights united bearing the atrocities unleashed by the alien Government and in the there is nothing left.

The narrator of all these epic happenings is a grandmother who is gifted with the art of storytelling to the new comer, the annals of her village, the events in which she had herself participated. His narrative style consists of spontaneity, swiftness empowered with native vigour. Skillfully and wittily he weaves the whole drama excitingly "mixing memory with desire "in this article very well.

\section{REFERENCES}

Rao Raja, Kanthapura: London, George Allen and Unwin, 1938 Print.

“ " The Serpent and the Rope. London: John Murray, 1960 Print.

“ “ The Policeman and the Rose. New Delhi: Oxford university Press, 1978 Print.

Anand, Mulk Raj. The old woman and the Cow.(Gouri), New Delhi: 1976 Print.

Desai, Anita. Bye-Bye Blackbird, New Dlhi: 1978 Print.

Iyengar, K.S. Srinivasa. Indian Writing in English, 1984 Print.

Krishnaswamy, Shanta. The woman in English Fiction in India, New Delhi, 1984.

Naik, M.K. A History of Indian English Literature, Sahitya Akademi, 1982 Print.

Narayan R.K. Waiting for the Mahatma, Mysore: 1958 Print.

\section{AUTHOR'S BIOGRAPHY}

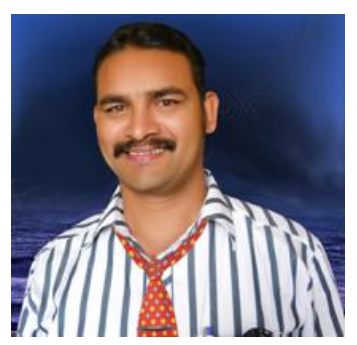

Dr.Venkateswarlu Yesapogu awarded his PhD degree in (2012) in the contemporary Indian fiction at the Acharya Nagarjuna University, GUNTUR, Andhra Pradesh, India, his M.A., M.Phil, also happened in the English literature. He is now teaching English Literature and Phonetics in V.V. \&M. Degree College ONGOLE. He became the youngest Principal FAC by virtue of awarded PhD and seniority among existing staff since 2009. His teaching is on main research interests including teaching of Phonetic Science as well as communication skills. He has recently published two books. The first entitled "The Fictional World of Amitav Ghosh" with ISBN 9789382186397; and published several other articles in reputed international journals. He has participated National and International seminars/conferences. 